Mirosław ROMAŃSKI

Uniwersytet Rzeszowski

\title{
Amerykański exceptionalism - wizja, mit czy rzeczywistość?
}

\section{American Exceptionalism - A Vision, A Myth or Reality?}

\begin{abstract}
The following article has a nature of a scientific essay and concerns the issues of „American exceptionalism" phenomenon still present in public debates. In spite of the fact that it has been permanently present in the US politics for many years and has its own premises resulting from the fist independence declarations and Constitution, it has the ups and downs.

The fundamental aim of that essay is to answer the question - to what extent exceptionalism and American uniqueness connected with it is important in politics of that country and world politics. Do the phenomenon of terrorism and the attitude of the USA to human rights go hand in hand with the idea of issues raised in that text?

The source basis for writing that article were the most important titles concerning the examined item and general conclusions of the Author after studying them.
\end{abstract}

Keywords: american exceptionalism, politics USA, role USA in world

Słowa kluczowe: amerykański exceptionalism, polityka USA, rola USA w świecie

American exceptionalism, zjawisko charakterystyczne w polityce wewnętrznej i międzynarodowej Stanów Zjednoczonych, towarzyszy temu krajowi od wielu lat. Problematyka ta wprawdzie poruszana była w różnych publikacjach naukowych i popularnonaukowych wydanych na Zachodzie, jest też powszechnie obecna w różnych esejach, drobnych tekstach oraz innych publikacjach, ale jak do tej pory nikt z badaczy polskich szerzej nie rozwinął tej interesującej kwestii. Charakterystyka omawianego zjawiska nie jest zadaniem łatwym, gdyż ma ono wielu przeciwników jak i zwolenników na całym świecie. Artykuł ten ma postać eseju naukowego i powstał w oparciu o źródła anglojęzyczne: literaturę przedmiotu, prasę oraz materiały internetowe.

Amerykański exceptionalism wynika w zasadzie z pierwszych zapisów konstytucyjnych Stanów Zjednoczonych i jest ściśle powiązany z demokracją w wydaniu 
amerykańskim. Zalążek wolności i podstawowych praw człowieka w USA razem ze zobowiązaniami ustrojowymi tego państwa, skoncentrowano już w Deklaracji Wirginii z 1776 r., poprzedzającej z kolei Deklarację Niepodległości Stanów Zjednoczonych. Została tam określona grupa praw, które przysługują każdemu człowiekowi, a wśród nich: równość, prawo do życia, wolność i szczęście ${ }^{1}$ Zapisy mówiły też, że władze USA powinny zmierzać do tego, żeby zabezpieczyć prawa obywatelskie, przewidując zgodę obywateli na rządy jak również możliwość ich obalenia przez obywateli ${ }^{2}$. Zobowiązania $\mathrm{w}$ dziedzinie poszanowania praw człowieka w USA zapisane zostały głównie w Deklaracji Niepodległości Ameryki Północnej. Skoncentrowano je w prawie do posiadania własności, oporze przeciwko uciskowi i niebezpieczeństwie, co miało duży wpływ na ukształtowanie się idei amerykańskiego exceptionalismu ${ }^{3}$. Obywatele uzyskali prawo do pełnego i swobodnego wyrażania swoich myśli i poglądów, oraz do wyznawania przekonań religijnych. Przy czym, prawa obywatelskie zostały wszystkim zagwarantowane. Wśród deklaracji wolności i równości, każdy obywatel miał mieć równy dostęp do wszelakich godności, stanowisk i funkcji publicznych. Każdy obywatel miał posiadać również gwarancję, że nie może zostać oskarżony, aresztowany czy też uwięziony. Zwierzchnictwo nad władzami spoczywało na Narodzie, a same władze miały być przez niego wybierane. Następnym bardzo istotnym zapisem były gwarancje uczestnictwa obywateli w pracach nad ustawami ${ }^{4}$. Kluczowym impulsem do stopniowego wyzwalania się i uformowania amerykańskiego exceptionalismu były gwarancje praw obywatelskich w USA, gdzie główną rolę odegrała Deklaracja Niepodległości z dnia 4 lipca 1776 r.5 Obowiązujące praktycznie do czasów współczesnych zobowiązania podjęte na Kongresie, były podstawą wolnego państwa i gwarancji praw człowieka. Ważny był zapis mówiący o tym, że każdy obywatel USA jest równy i został obdarzony przez Stwórcę nienaruszalnymi prawami. Aby je zagwarantować ludzie powołali sprawiedliwe rządy ${ }^{6}$.

Wywodzący się z prawodawstwa USA oraz stylu i charakteru państwa, amerykański exceptionalism, wiąże się ze swego rodzaju odrębnością i wyjątkowością

The Virginia Declaration of Rights, http://www.constitution.org/bcp/virg_dor.htm\#001, odczyt z 2.01.2014.

2 The Federal and State Constitutions, Colonial Charters, red. F. N. Thorpe, Washington 1909, s. $3-14$.

3 R. Iviea, O. Ginerb, American Exceptionalism in a Democratic Idiom: Transacting the Mythos of Change in the 2008 Presidential Campaign, Communication Studies, 2009, 60/4, s. 35-75.

4 The Federal and State Constitutions...

5 A. Bartnicki, K. Michałek, I. Rusinowa, Encyklopedia Historii Stanów Zjednoczonych Ameryki, Warszawa 1992, s. 67-68.

6 Ibidem. 
Stanów Zjednoczonych na arenie światowej. Według tego poglądu USA różnią się od innych państw mając nakreśloną swego rodzaju misję w świecie, której nadrzędnym celem jest propagowanie modelu wolności oraz państwa demokratycznego. Nie oznacza to jednak, że USA są lepsze od innych krajów i mają lepszą kulturę7. Chodzi raczej o to by „model USA naśladowany był przez resztę świata, ponieważ warunki w których zrodziły się Stany Zjednoczone nie mogły być powtórzone gdzie indziej"".

Amerykański exceptionalism był terminem używanym z różnych względów. Należy dodać, że trudno było zinterpretować ową wyjątkowość i wspaniałość. Miały tutaj na pewno ważną rolę uczucia, wartości i patriotyzm, choć pojęcia te były różnie rozumiane w innych krajach Zachodu. Twórcy i założyciele Ameryki byli w każdym razie przekonani, że tworzą coś niezwykłego. Dowodzi tego motto novus ordo seclorum zamieszczone na odwrocie Wielkiej Pieczęci Stanów Zjednoczonych, co oznacza „nowy porządek wieków”.

Amerykański exceptionalism wiąże się ze swoistą rewolucją, cytując socjologa Seymour Martina Lipseta, który określił USA jako pierwszy wolny naród i rozwinął amerykańską ideologię na podstawie pojęć wolności, egalitaryzmu, indywidualizmu, leseferyzmu i populizmu ${ }^{10}$. Mimo że termin exceptionalism nie oznacza wyższości, duża grupa neokonserwatystów wraz amerykańskimi konserwatywnymi pisarzami rozpowszechniała go pod tym kątem. Dla tych środowisk Stany Zjednoczone były niczym biblijne miasto na wzgórzu, uwolnione od historycznych dramatów, które dotknęły inne państwa. Później, zwłaszcza od początku lat sześćdziesiątych XX w. naukowcy odrzucili amerykański exceptionalism, sądząc że USA nie zrodziły się z kultury europejskiej ${ }^{11}$. De facto, poczucie wyjątkowości tego kraju dokonało się najpierw na terenie Europy, jeszcze nim została odkryta. Wówczas panowało przekonanie, że istnieje utopijna przestrzeń, w której życie może być lepsze, ale okazało się że owa „wyjątkowość” odnosi się tylko do Północy. Istotny wpływ na powstanie takiego poglądu mieli purytanie, którzy w latach trzydziestych XVII w. doprowadzili do powstania kolonii w Massachusetts i ogłosili, że będzie ona Miastem na Wzgórzu, na którym skoncentruje się uwaga

7 D. Ross, American Exceptionalism in A Companion to American Thought, London 1995, s. $22-23$.

8 I. Tyrrel, What is American exceptionalism?, http://iantyrrell.wordpress.com/papers-andcomments/, odczyt z 19.01.2014.

9 Ch. Murray, American Exceptionalism An Experiment in History, b. r. w., s. 5-6.

10 S. Lipset, American Exceptionalism: A Double-Edged Sword, New York 1996, s. 98; Review Essays American Exceptionalism, The American Historical Review, June 1997, nr 102/3, s. 748.

${ }_{11}$ Ibidem, s. 17-19, 165-174, 197. 
świata ${ }^{12}$. Według założycieli Massachusetts, Ameryka miał być miejscem gdzie Pan stworzy nowe niebo, nową ziemię w kościołach, oraz nową wspólnotę wszystkich narodów ${ }^{13}$. Jednakże pierwotne poglądy i zalążek idei „wyjątkowości” mają genezę w kolebce Stanów Zjednoczonych ${ }^{14}$. Termin exceptionalism przypisany jest Alexis de Tocqueville, który zauważył, że USA zajęły szczególne miejsce wśród narodów, ponieważ był to kraj imigrantów i pierwsza demokracja ${ }^{15}$. Według niego, na uczynienie Ameryki wyjątkową złożyło się zaangażowanie w wolność, egalitaryzm, indywidualizm, populizm i leseferyzm ${ }^{16}$. Demokracja ta miała dążyć do moralnego odrodzenia ludzkości, unikania międzynarodowych konfliktów, oraz stanowić liberalne podejście w relacjach międzynarodowych ${ }^{17}$.

Walka o niepodległość USA czerpana była z tradycji republikanizmu, z którego brytyjski nurt główny zrezygnował. Historyk Gordon Woods spierał się, że przekonania o wolności, równouprawnieniu, konstytucjonalizmie i dobru ludzi, wyszły z ery rewolucyjnej. Z tego względu twierdził, że Amerykanie są ludźmi wyjątkowymi oraz przodującymi w działaniach na świecie w kierunku wolności i demokracji. Przekonanie, że USA to nie tylko „przedłużenie Europy”, ale państwo o nieograniczonym potencjale, wyrosło z brytyjskiego kraju ojczystego, przyłożyło intelektualne podstawy dla rewolucyjnego pojęcia amerykańskiego exceptionalismu, mając przy tym bliski związek z republikanizmem. Zatem amerykański exceptionalism stawiał USA w wyjątkowym położeniu i roli, zakładając że demokracja jaka występuje w tym kraju nie będzie nigdy w żadnym innym. Przekonanie, że USA są źródłem dobra na całej ziemi, ma tutaj znacznie szczególne. Wiąże się to niewątpliwie z faktem, że uratowały Europę od okropieństw wojen. Często spotykany obecnie tzw. antyamerykanizm, poddający ideę exceptionalismu w wątpliwość, trwale obecny w świecie, jest zazwyczaj podyktowany tym, że na scenie międzynarodowej nie są zrozumiałe dobre intencje USA, oraz tym,

12 W. Mondale, American Exceptionalism, Global Security, and Human Dignity: The Great Challenge of the $21^{\text {st }}$ Century, University of St. Thomas Law Journal, 2005, nr 3/2, s. 169-170.

13 L. Baritz, City on a Hin: A History of ldeas and Myths in America, New York 1964, s. 3.

14 D. Drezner, The Realist Tradition in American Public Opinion, Perspectives on Politics, March 2008, nr 6/1, s. 53; T. Bender, Czy Ameryka jest wyjattkowa?, http://wyborcza.pl/1,117325,4510108. html, odczyt z 23.12.2013.

15 J. Thimm, American Exceptionalism - Conceptual Thoughts and Empirical Evidence, Berlin 2013, s. 3.

16 P. Frickey, (Native) American Exceptionalism In Federal Public Law, Harvard Law Review, 2005, nr 119/ 431, s. 434.

17 R. Barnet, Roots of War, New York 1972, s. 251; W. Doyle, Liberalism and World Politics, American Political Science Review, December 1986, nr 4, s. 1151-1169. 
że generalnie nie darzy się sympatią bogatych. Z drugiej strony, spora grupa krytykujących chciałaby żyć tak jak Amerykanie ${ }^{18}$.

Termin exceptionalism posiada dwie formy: łagodną i agresywną. Pierwsza z nich wiąże się z wystąpieniem Abrahama Lincolna po zwycięstwie Północy nad Południem pod Gettysburgiem w 1863 r., gdzie powiedział że USA jest ostatnią i największą nadzieją rodzaju ludzkiego. Po tym dodał, że istnieje potrzeba stworzenia modelowego społeczeństwa ludzi równych. Wersja łagodna była z kolei odzwierciedleniem aspiracji Stanów Zjednoczonych do zbudowania społeczeństwa szczęśliwego. Pierwsza wersja była hasłem głoszonym przez prezydenta Georga W. Busha, który twierdził, że sam Bóg powołał go do propagowania na arenie międzynarodowej wolności w stylu amerykańskim. Termin american exceptionalism miał też znacznie w Amerykańskiej Partii Komunistycznej i był powszechnie używany po dojściu do władzy komunistów w ZSRR. Określenie to związane jest z krytyką radzieckiego przywódcy Józefa Stalina przez zwolenników Jay Lovestone za przekonanie, że USA były niezależne od marksistowskich praw historii, co miało wpływ na bogactwa naturalne, zdolności produkcyjne oraz brak sztywnych różnic klasowych ${ }^{19}$. Termin w zasadzie był przez pół wieku nie do końca jasny, dopóki nie został spopularyzowany przez amerykańskie gazety w 1980 r., kiedy opisano kulturową i polityczną wyjątkowość USA ${ }^{20}$.

Istotną rolę odgrywał również amerykański exceptionalism w kwestii powszechnych praw człowieka. Już prezydent USA Thomas Jefferson w XIX w. był zwiastunem nowej dyplomacji, opartej na poszanowaniu człowieka wolnego i prawego, co z kolei miało umocnić ideę propagowania wolności jednostek, a także ogólnych praw człowieka. Jefferson ponadto zabiegał o zerwanie z tradycyjnym europejskim naciskiem na rację stanu. Podstawowym priorytetem jego polityki były prawa człowieka w ramach rodziny, które uznał za stojące ponad wszelkimi potrzebami ${ }^{21}$. Polityka poszanowania praw człowieka związana była u niego z wyobrażeniem o Stanach Zjednoczonych jako wielkim imperium wolności, które jest gwarantem dla demokracji oraz republikanizmu. Określił Amerykę jako kraj stanowiący na świecie jedyny pomnik poszanowania praw człowieka. Już wtedy amerykański exceptionalism wiązał się z pewnego rodzaju misją na dro-

18 Amerykańska wyjątkowość, www.przeglad-tygodnik.pl, odczyt z 23.12.2013.

19 T. McCoy, How Joseph Stalin Invented American Exceptionalism, http://www.theatlantic. com/politics/ar-chive/2012/03/how-joseph-stalin-invented-american-exceptionalism/254534, odczyt z 15.01.2014.

20 R. Iviea, O. Ginerb, op. cit., s. 359-375.

21 L. Hartz, The Liberal Tradition in America, New York 1955, s. 23-26; S. Huntington, American Politics: The Promise of Disharmony, Cambridge 1981, s. 45-50. 
dze do pełnej autonomii oraz dobroczynnego wpływu USA na resztę świata. Stany Zjednoczone były wówczas siłą napędową w propagowaniu globalnych praw człowieka, choć nie odzwierciedlały tego przepisy międzynarodowe. De facto, już wtedy istniało w USA głębokie przekonanie, że wartości odnoszące się do praw człowieka są uniwersalnym ich ucieleśnieniem ${ }^{22}$.

$\mathrm{Na}$ początku XX w. USA postrzegane były jako „kraj szans”, wobec czego szczyciły się obecnością exceptionalismu, na swój sposób uprawiając autoreklamę ${ }^{23}$. Na przykłady tej mobilności społecznej składały się różne czynniki. Dzieci mogły wybierać same swe kariery, i nie miały tutaj znaczenia decyzje rodziców ${ }^{24}$. Również położenie geograficzne nie decydowało o pozostaniu w miejscu urodzenia, a obywatele często przenosili się swobodnie na duże odległości ${ }^{25}$. Status społeczny nie różnicował ludzi i częstokroć zdolne dzieci nie pochodzące z zamożnych rodzin o wysokiej pozycji społecznej, miały możliwość osiągnąć wysoki status. Nadmienione aspiracje zostały powszechnie ogłoszone jako amerykańskie marzenie, co było odstępstwem od innych krajów, gdzie wyższa pozycja społeczna przypisana była tylko wywodzącym się z elit ${ }^{26}$. Zatem biorąc pod uwagę powyższe, kształtowano wizerunek USA jako państwa dobrobytu, opiekuńczego i wyjątkowego pod względem gospodarki, wydatków na cele publiczne i korzyści wynikających z polityki społecznej ${ }^{27}$.

Istnieje również pogląd, że na ukształtowanie się amerykańskiego exceptionalismu mógł wpłynąć proces powstania granic Stanów Zjednoczonych. Według tego poglądu, amerykańskie granice pozwoliły rozkwitnąć indywidualizmowi, ponieważ pionierzy przyjęli demokrację i równouprawnienie, rezygnując z doświadczeń europejskich ${ }^{28}$. Jednak każdy naród ma całkiem inne doświadczenia graniczne ${ }^{29}$. Przykładowo, holenderscy Afrykanerzy w Afryce Południowej zostali zwyciężeni

22 American Exceptionalism and Human Rights, www.foreignaffairs.com/articles/61039/gjohn-ikenberry/ american-exceptionalism-and-human-rights, odczyt z 15.01.2014.

23 H. Kaelble, Social Mobility in the Nineteenth and Twentieth Centuries: Europe and America in Comparative Perspective, New York 1981, s. 45-60.

24 S. Thernstrom, The Other Bostonians: Poverty and Progress in the American Metropolis, 1880-1970, Cambridge 1999, s. 10-25.

25 Ch. Stephenson, R. Jensen, J. Webster, Social Predictors of American Mobility: A Census Capture-Recapture Study of New York and Wisconsin, 1875-1905, New York 1978, s. 44-57.

26 P. Blau, O. Dudley, The American Occupational Structure, London 1978, s. 45-55.

27 R. Rose, How Exceptional is the American Political Economy?, Political Science Quarterly, 1989, nr 104/1, s. 91-92.

28 R. Etulain, Does the Frontier Experience Make America Exceptional?, New York 1999, s. $20-26$.

29 F. Schaefer, Exceptionalism in Geography: A Methodological Examination, Annals of the Association of American Geographers, September 1953, nr 43/3, s. 226-249. 
w wojnie przez Wielką Brytanię. W Australii współdziałanie znaczyło więcej niż indywidualizm w USA, dzięki któremu ukształtowały się „amerykański duch” i „amerykańska tożsamość”30.

Orędownikiem tożsamości Stanów Zjednoczonych był na początku XX w. Woodrow Wilson prezydent USA w latach 1913-1921, stawiający ją ponad wszelkie wartości. Według niego, Ameryka była kontynentem pod opatrznością bożą i zasiedlonym przez ludzi kochających wolnośćs ${ }^{31}$. Wilson utrzymywał, że nieangażowanie się w I wojnę światową pozwoli Stanom Zjednoczonym zachować czystość i będzie stanowić moralny przykład dla świata. Jednak owa neutralność okazała się niewykonalna, i kiedy Ameryka do wojny przystąpiła, exceptionalism posiadał już inną postać. Mimo zaangażowania się USA w konflikt, w następnych latach (zwłaszcza do 1941 r.), Stany Zjednoczone starały się utrzymywać pogląd mówiący o tym, że należy stronić od uczestnictwa w ogólnoświatowych sporach wynikających z działań wojennych ${ }^{32}$.

Inną formę miał amerykański exceptionalism po II wojnie światowej, kiedy działania Stanów Zjednoczonych na forum międzynarodowym sprowadzały się $\mathrm{w}$ istocie do podporządkowania traktatom i konwencjom w sprawie praw człowieka. Rezultatem tego było połączenie praw zagwarantowanych w konstytucji USA z międzynarodowymi prawami człowieka ${ }^{33}$. Wywołało to szereg trudności we wprowadzeniu traktatów w życie, oraz opór przeciwko uniwersalizacji praw na terenach wielu krajów, gdzie instytucje międzynarodowe utworzone z inspiracji USA postrzegano jako chcące narzucić wartości i kulturę USA. Zatem exceptionalism i światową misję USA mającą na celu powszechne dobro i poszanowanie praw człowieka, de facto odbierano jako próbę narzucenia światu polityki amerykańskiej. Nie stroniono od zarzutów wobec Stanów Zjednoczonych, że łamią prawo międzynarodowe. Nie należy jednak poddawać ostrej krytyce tej polityki, ponieważ państwo to po wojnie przyniosło wszystkim demokrację i rządy ludzi prawa, a od czasu stworzenia ONZ zażegnało reżimy łamiące i nie respektujące powszechnych praw człowieka. Z tego względu, jeżeli wszystkie traktaty byłyby obierane poważnie, należało je zgodnie z ideą amerykańskiego exceptionalismu

30 D. Carroll, Mateship and Individualism in Modern Australian Drama, Theatre Journal, 1982, nr 34(4), s. 467-480.

31 W. Wilson, A Commencement Address at the United States Military Academy, West Point, 13.06.1916, nr 16, s. 12-15.

32 R. Patman, Globalisation, the New US Exceptionalism and the War on Terror, Third World Quarterly, 2006, nr 27/6, s. 965-966.

33 J. Resnik, Law's Migration: American Exceptionalism, Silent Dialogues, and Federalism's Multiple Ports of Entrys, The Yale Law Journal, 2006, nr 115/1564, s. 1598. 
rozumieć w znaczeniu historycznym, i mieć na uwadze, że odnosiły się do ujęcia tychże w skali globalnej, a celem ich miało być powszechne dobro.

Po II wojnie światowej USA usiłowały uniknąć błędów dwudziestolecia międzywojennego, a exceptionalism miał jeszcze raz zagwarantować kluczowe sprawy. Prezydent Harry Truman mówił, że jego polityka zagraniczna będzie dążyć do sprawdzenia czy wypracowane wcześniej koncepcje wprowadzane zostały w życie. Obecny w okresie „zimnej wojny” exceptionalism osiągnął poziom szczytowy w 1960 r. Prezydent John Kennedy postulował wtedy, żeby płacić jakąkolwiek cenę, dźwigać brzemię, spotykać się z biedą, pomagać nieprzyjacielowi, stawiać opór wrogom, gwarantować przetrwanie i sukces wolności. Zatem aspekt „misyjny” amerykańskiego exceptionalismu został znów podniesiony do rangi szczególnej ${ }^{34}$.

Przełomowym momentem dla amerykańskiego exceptionalismu była masakra w Mỹ Lai, która miała miejsce dnia 16 marca 1968 r., i dokonana została przez armię amerykańską. W wiosce na terenie południowego Wietnamu uległy jej setki nieuzbrojonych cywilów. Wydarzenie wywołało oburzenie na całym świecie, przyczyniając się do spadku poparcia dla wojny wietnamskiej w USA, a także znacznie osłabiając ideę exceptionalismu ${ }^{35}$.

Od końca II wojny światowej USA przodowały w naukowym i technicznym postępie. Intensywny rozwój sektora prywatnego, zaawansowane badania naukowe ośrodków uniwersyteckich, rozwój przemysłu, innowacje w dziedzinie podboju kosmosu, udział w nowatorskich przedsięwzięciach utalentowanej kadry, zapoczątkowywały utrzymywany przez wiele lat wzrost gospodarczy oparty na nowej wiedzy i pomysłach ${ }^{36}$. O ile w latach sześćdziesiątych XX w. amerykański exceptionalism powszechny był w życiu publicznym USA, o tyle już w 1975 r. upadek jego prognozował socjolog Uniwersytetu Harvarda - Daniel Bell ${ }^{37}$. Jednak już w latach osiemdziesiątych okazało się, że są to przedwczesne prognozy. Podczas prezydentury Ronalda Reagana USA odzyskały wiarę w siebie, a obywatele kolejny raz poczuli się dobrze we własnym kraju, będąc świadomymi jego roli w świecie. Exceptionalism dekady lat osiemdziesiątych sławił wyjątkowość, narodowe cnoty, podniósł rangę moralną Ameryki, a także propagował amerykańskie ideały

34 T. Davis, S. Lynn-Jones, Citty Upon a Hill, Foreign Policy, Spring 1987, nr 66, s. 25-26.

35 K. Oliver, Atrocity, Authenticity and American Exceptionalism: (Ir)rationalising the Massacre at My Lai, Journal of American Studies, 2003, nr 37/2, s. 247-268.

36 S. Jacoby, American Exceptionalism Revisited: The Importance of Management, Los Angeles 1987, s. 5; American Exceptionalism, American Decline? Research, the Knowledge Economy, and the 21st Century Challenge, December 2012, s. 4.

37 D. Bell, The end of American Exceptionalism, Parameters. Journal of the US Army War College, 1975 , $\mathrm{nr}$ X/2, s. 2-18. 
na świecie. Krytyczne głosy wobec exceptionalismu podczas dekady lat osiemdziesiątych oscylowały wokół zarzutów, że Amerykanom brak wspólnego etnicznego i językowego spadku, dlatego posiadają skłonności do konstruowania tożsamości narodowej z przekonań o ich własnej wyjątkowości ${ }^{38}$. Wyjątkowość połączona z amerykańską tożsamością pociągała za sobą z kolei misyjną rolę Stanów Zjednoczonych w świecie ${ }^{39}$.

Jimmy Carter - prezydent USA w latach 1977-1981 z trudem podejmował przywrócenie wiary w exceptionalism i umacnianie przekonania o specjalnej misji w świecie. Obiecując to, lansował przekonanie mówiące, że istnieje konieczność odzyskania postawy moralnej Ameryki, oraz że zadaniem Stanów Zjednoczonych jest służenie całej ludzkości. Wysiłki prezydenta idące w kierunku przywrócenia wiary w instytucje amerykańskie i popieranie praw człowieka, stanowiły istotny i znaczący element jego programu, koncentrującego się na odbudowie pozycji moralnej USA. W 1979 r., kiedy Związek Radziecki dokonał inwazji w Afganistanie, exceptionalism nieco osłabł potęgując amerykańską bezsilność i niekompetencję, co z kolei sprawiło że wysiłki Cartera ostatecznie usunięte zostały w cień, by umocnić wizję wyjątkowo prawej Ameryki w wydarzeniach światowych ${ }^{40}$.

Roland Reagan, prezydent Stanów Zjednoczonych w latach 1981-1989, odziedziczył po swoim poprzedniku prawą politykę zagraniczną, choć przyozdobił ją retoryką, powiązując z wizerunkiem siły i zaufania. W kwestii exceptionalismu mówił o USA jako „narodzie losu” i wskrzesił kolonialny pomysł USA jako „miasta na wzgórzu”¹ . Przemówienia Reagana charakteryzował tryskający energią optymizm twórców amerykańskiej konstytucji oraz idealizm Wilsona. W 1984 r. New York Times podał, że Ameryka jest najspokojniejszym i najmniej wojowniczym narodem w historii nowożytnej ${ }^{42}$. Retoryka prezydenta Reagana koncentrowała się na kontraście między prawą Ameryką i komunistycznym Związkiem Radzieckim. Polityka tego typu zdominowała i nadała kształt administracji prezydenta. Jego rozmowy w kwestii krucjaty na rzecz wolności ostatecznie wywołały wysiłki, żeby rozpowszechniać demokrację przy pomocy wsparcia antykomunistycznych ruchów partyzanckich w Afganistanie, Angoli, Kambodży i Nikaragui ${ }^{43}$. Prze-

38 T. Davis, S. Lynn-Jones, op. cit., s. 20-22.

39 H. Restad, Old Paradigms in History Die Hard in Political Science: US Foreign Policy and American Exceptionalism, American Political Thought, Spring 2012, nr 1/1, s. 62.

40 T. Davis, S. Lynn-Jones, op. cit., s. 27-29.

41 New York Times, 19.08.1980, nr 44, s. 1-2.

42 Ibidem, 24.08.1984, nr 56, s. 3-4.

43 The Poverty of Realism, New Republic, 17.02.1986, nr 22, s. 14-22; Morality and the Reagan Doctrine, ibidem, 8.09.1986, nr 78, s. 17-24. 
konania o amerykańskiej wyjątkowości i moralnej wyższości widoczne były również w debatach publicznych, co wywołało znaczne kontrowersje. Amerykański exceptionalism $\mathrm{w}$ wydaniu Reagana znalazł poparcie wśród neokonserwatystów, którzy chwalili prezydenta za nacisk na wyjątkową cnotę Ameryki ${ }^{4}$. Retoryczny akcent na amerykański exceptionalism odzwierciedlony został w postawach obywateli, bo ankiety przeprowadzone w 1983 r. stwierdziły, że 81\% Amerykanów wierzy, iż kraj w którym żyją posiada szczególną rolę w świecie ${ }^{45}$. Jednak przekonanie o wyjątkowości społeczeństwa USA lansowane przez prezydenta Reagana, a także obecne w 1987 r. podczas obchodów rocznicy Konstytucji USA określenia o latarni nadziei dla innych narodów, przewodniej sile połączonej z opatrznością, wyższych celach USA w postaci ochrony ludzkości i świętego obowiązku w świecie, o ile miały swe uzasadnienie w kontekście historycznym, o tyle wzbudzały w oczach opinii światowej kolejne kontrowersje ${ }^{46}$.

Na przełomie lat osiemdziesiątych i dziewięćdziesiątych XX w., kiedy prezydentem Stanów Zjednoczonych był George Bush, termin amerykański exceptionalism został nieco wyciągnięty ze swojego kontekstu historycznego. Najczęściej jednak używano go przy poruszaniu tematu postrzegania przez Stany Zjednoczone prawa międzynarodowego. Zjawisko to było mniej związane z usprawiedliwianiem amerykańskiej wyjątkowości niż z manifestowaniem jego odporności na prawo międzynarodowe. Jednak na ogół wykorzystanie terminu służyło, ażeby mylić temat odkąd jego unilateralny akcent oraz historyczna orientacja różniły się nieco od starszych wykorzystań terminu ${ }^{47}$.

Przełomową datą w uwzględnianiu globalnych praw człowieka i roli amerykańskiego exceptionalismu były wydarzenia z roku 2001 i zamachy na World Trade Center. Wówczas przywódcy Stanów Zjednoczonych dążyli do szybkiego zidentyfikowana źródła gróźb światowego terroryzmu, a także ich wyjaśnienia. $\mathrm{Z}$ drugiej strony, odzywało się wiele głosów krytycznych mówiących, że skoro Stany Zjednoczone nie respektują praw człowieka i lekceważą prawo międzynarodowe, to innym państwom wolno postępować tak samo. Takie podejście do USA nie zagwarantuje nigdy tego, co państwo to życzyło sobie od dawna, a mianowicie osiągnięcie wspólnego porozumienia i zaakceptowania formuły że amerykański exceptionalism stanowiący fundament dla obecnej polityki globalnej USA, będzie

\footnotetext{
44 See his "Isolationism, Left and Right”, ibidem, 4.03.1985, nr 30, s. 25.

45 B. Wattenberg, The Good News Is the Bad News Is Wrong, New York 1984, s. 362.

46 F. Fitzgerald, Way Out There in the Blue: Reagan, Star Wars and the End of the Cold War, New York 2000, s. 24.

47 C. Philippe, D. Grondin, Hegemony or empire? The redefinition of US power under George W. Bush, Burlington 2006, s. 9-15.
} 
musiał stanowić nierozerwalny tandem z powszechnym poszanowaniem praw człowieka i jego godności, być w pełni akceptowany, a nie powodować sporów, antagonizmów i głosów sprzeciwu, niejednokrotnie tak radykalnych i skrajnych jak zamachy terrorystyczne. Amerykański exceptionalism od 2001 r. intensywnie powrócił do debat publicznych i do polityki zagranicznej Stanów Zjednoczonych $^{48}$. Miało to głównie wyraz w lansowanym przez administrację prezydenta Georga Busha patriotyzmie i pielęgnowaniu ideałów ${ }^{49}$. Określeniu przez Busha w styczniu 2002 r. jako „osi zła” Iraku, Iranu i Korei Północnej, towarzyszyły wzniosłe nowomowy o wolności danej Ameryce jako nagrodzie oraz prezencie dla świata i ludzkości od Boga. Przemówienie to spowodowało znaczne poruszenie na całym świecie. W rezultacie wielu sojuszników Ameryki zwątpiło w sens tych słów i pokonanie terroryzmu ${ }^{50}$.

Po wydarzeniach z 2001 r. amerykański exceptionalism posiada całkiem odmienny charakter. Stawia go to, z uwagi na globalne zagrożenia terroryzmem, przed następnymi wyzwaniami. Ważną rolę odgrywa tutaj fundamentalna zasada polityki Stanów Zjednoczonych, czyli tzw. worldview, zakładający cywilizację zachodnią jako najważniejszą scenę procesu rozprzestrzeniania przyjaźni, dobra, poszanowania praw każdego człowieka i pełnego rozwoju ludzkiego. Styl funkcjonowania różnych państw może owszem charakteryzować polityka przestrzegania i poszanowania praw człowieka, swobody obywatelskie i utrzymywanie przyjaznych stosunków, ale amerykański exceptionalism w rozumieniu amerykańskim jest ponad nimi, wszak to system najbardziej zaawansowany ${ }^{51}$.

Niezmiernie ważne jest pełne poparcie przez państwa całego świata idei amerykańskiego exceptionalismu. Przy czym istotne jest, że stosowanie się do prawa międzynarodowego Stanów Zjednoczonych wiąże się z faktem, że jest to system prawny w wielu przesłankach i doktrynach wiążący się z Europą, z której się w zasadzie wywodzi. Tego typu stwierdzenia koncentrują się na wierze w jedyną uniwersalną drogę postępu ludzkiego. Biorąc pod uwagę rozprzestrzeniający się globalny terroryzm oraz brak poszanowania praw człowieka, system uniwersalizmu i swego rodzaju przyzwolenie Stanów Zjednoczonych do decydowania o światowym porządku, na skutek zagrożeń zaczyna ulegać osłabieniu ${ }^{52}$. Opór wobec amerykań-

48 N. Saito, Human Rights, American Exceptionalism, and the Stories We Tell, Emory International Law Review, 2009, nr 23, s. 54.

49 J. Ostrander, Changing Direction on Non-Nuclear Arms Control-American Exceptionalism, Power, and Constancy, Berkeley Journal of International Law, 2003, nr 21/3, s. 496.

50 R. Patman, op. cit., s. 975.

51 N. Saito, op. cit., s. 54.

52 Ibidem, s. 55-56. 
skiego exceptionalismu i powszechnego wprowadzenia wartości zachodnich często przedstawia się jako próba powrotu do przedoświeceniowego etapu cywilizacji, w której społeczeństwa rządzone były twardą ręką. Tym samym, usiłuje się w wielu debatach dopuszczać do praktyk odstępujących od modelu amerykańskiego.

Powszechny opór przeciw narzucaniu polityki Stanów Zjednoczonych światu wiąże się z braniem pod uwagę, zwłaszcza przez ludność autochtoniczną, utrzymanie ich tożsamości, zachowanie własnej historii, kultury, religii, systemu zdrowia i edukacji, statusu politycznego oraz niezależności.

Amerykański exceptionalism ma współcześnie zupełnie inny wymiar niż w czasie, kiedy Stany Zjednoczone ukształtowały się jako kraj niezależny, nie mając wpływu na politykę światową w kwestii praw człowieka, i nie wydając regulacji prawnych odnoszących się do tych kwestii. Zaangażowanie USA w politykę globalną, branie przez nie udziału w ustanawianiu prawa międzynarodowego, oraz swego rodzaju misja dziejowa tego kraju polegająca na budowaniu powszechnego dobra i stawianiu go w roli wyjątkowego narodu, wydaje się w dobie powszechnych zagrożeń globalnych, bardzo skomplikowana. Nie należy jednak piętnować polityki i zaangażowania USA w politykę światową, bo dojście do konsensusu mając na uwadze tak dużą różnorodność kultur, ustrojów, przekonań politycznych, religijnych i społecznych, wymaga wielostronnego zaangażowania w dialog.

Pojęcie amerykańskiego exceptionalismu w XX/XXI w. ściera się z pojęciem demokracji, co ma swój wyraz w coraz częściej używanym pojęciu „globalnej rewolucji demokratycznej" ${ }^{33}$. Ustrój demokratyczny jest z kolei związany z respektowaniem praw człowieka, gdyż kwestie te nawzajem się przenikają i warunkują. Wiele debat toczonych w międzynarodowym życiu publicznym stawia współcześnie za cel odpowiedź na zasadnicze pytanie: czy istnieje możliwość postawienia znaku równości między demokracją a prawami człowieka? Odpowiedzi na to pytanie jest mnóstwo, ale problematyka nadal jest przyczyną wielu kontrowersji ${ }^{54}$.

Kontrowersje wokół zjawiska amerykańskiego exsceptionalismu wywołują również polemiki wśród naukowców ${ }^{55}$. Współcześni historycy tacy jak Thomas Bender, usiłowali położyć kres ożywieniu dyskusji nad amerykańskim exceptionalismem, upatrując go w kategoriach dziedzictwa „zimnej wojny”. W spór zaangażowali się też Gary Reichard i Ted Dickson, którzy nie podzielili poglądu że efektem wypracowania przez USA poszczególnych dóbr była współpraca

53 D. Rustow, Democracy: A Global Revolution?, Foreign Affairs, 1990, s. 34-38.

54 The Encyclopedia of Democracy, s. 577.

55 S. Jasanoff, American Exceptionalism and the Political Acknowledgment of Risk, Daedalus, Fall, 1990, nr 4, s. 61-81. 
$\mathrm{z}$ innymi narodami w dziedzinie towarów, wartości kulturowych oraz populacji ${ }^{56}$. Ideę wyjątkowej roli Stanów Zjednoczonych skrytykował również Roger Cohen, który wątpił czy USA mogą być wyjątkowe, skoro stoją otwarcie przed głównymi problemami terroryzmu i rozprzestrzeniania broni jądrowej57. Tego typu pogląd charakterystyczny był też dla Harolda Koha ${ }^{58}$ i Godfreya Hodgsona, którzy twierdzili, że amerykański mit narodowy jest w istocie niebezpieczny ${ }^{59}$. Powszechnie panujący pogląd, że Ameryka stanowi wzór obaliła Samantha Power ${ }^{60}$, a także sceptycznie do niego ustosunkowany Brytyjczyk Godfrey Hodgson, twierdzący, że „nie ma nic nadzwyczajnego w wyjątkowości Stanów Zjednoczonych, ponieważ wszystkie wielkie narody pielęgnują swe mity narodowe"61.

Również wśród polityków zdania co do amerykańskiego exceptionalismu są bardzo podzielone. Termin ten używany był podczas prezydenckiej kampanii wyborczej między kandydatami Barackiem Obamą i Johnem McCainem w 2008 r. ${ }^{62}$ Był również przedmiotem polemiki w r. 2009 pomiędzy Barackiem Obamą i starającym się o fotel prezydenta USA Mittem Romneyem. Różnice w postrzeganiu exsceptionalismu polegały na tym, że Obama biorąc pod uwagę ogrom wyzwań stojących przez Ameryką, uznał potrzebę budowania partnerstwa z innymi państwami na świecie, po to żeby wspólnie rozwiązywać problemy ${ }^{63}$. Z kolei Mitt Romney kojarzył ten termin z jego klasyczną formą stawiającą USA na samodzielnym stanowisku ${ }^{64}$. W dyskusję włączył się były gubernator stanu Arkansas Mike Huckabee, który upatrywał w Obamie bardziej globalnego przywódcę niż amerykańskiego, co z kolei dowieść miało, że współczesny amerykański exsceptionalism w istocie zaprzecza sercu i duszy tego narodu ${ }^{65}$. W 2010 r. młody senator Partii

56 G. Reichard, T. Dickson, America on the World Stage, Illinois 2008, s. 327.

57 R. Cohen, Palin's American exception, International Herald Tribune, 30.12.2011, nr 55, s. $9-12$.

58 https://web.archive.org/web/20060911215819/http://web.pdx.edu/ kinsella/ps448/koh.html, odczyt z 15.01.2014.

59 G. Hodgson, The Myth of American Exceptionalism, New Aven 2009, s. 69-100.

60 M. Hirsch, No Time to Go Wobbly, Barack, http://www.washingtonmonthly.com/, odczyt z 15.01.2014.

${ }^{61}$ G. Hodgson, op. cit., s. 14.

62 R. Iviea, O. Ginerb, op. cit., s. 359-375.

63 J. Kirchick, Squanderer in chief, Los Angeles Times, 28.04.2009, nr 24, s. 3-6.

64 M. Sheer, On European Trip, President Tries to Set a New, Pragmatic Tone, The Washington Post, 5.04.2009, nr 23, s. 3-5; M. Romney, No Apology: The Case for American Greatness, New York 2010, s. 12.

65 M. Jonathan, B. Smith, The New Battle: What It Means to be American, www.politico.com/ news/stories/08 10/41273.html, odczyt z 18.01.2014. 
Republikańskiej Marco Rubio uczynił również temat exceptionalismu głównym wątkiem kampanii wybiorczej na Florydzie ${ }^{66}$.

Propagowanie wiary $\mathrm{w}$ amerykański exsceptionalism przez prezydenta USA Baracka Obamę widoczne jest dość często ${ }^{67}$. Dla przykładu, we wrześniu 2013 r. podczas przemówienia odnośnie do kryzysu w Syrii, Obama powiedział, że USA może powstrzymywać dzieci od nieszczęść i tym samym otoczyć je bezpieczeństwem, co czyni Amerykę inną i wyjątkową. Tego typu wypowiedzi wywołują niejednokrotnie refleksje czy prezydent Obama rzeczywiście wierzy w exsceptionalism, czy chce w niego wierzyć na każdym kroku usiłując go propagować oraz przypominać ${ }^{68}$. Jego wypowiedzi, że Anglicy wierzą w brytyjski exceptionalism a Grecy w grecki, potwierdzają tylko retorykę opartą na przypominaniu o wyjątkowości Stanów Zjednoczonych ${ }^{69}$.

Współcześnie idea amerykańskiego exceptionalismu w praktyce ulega stopniowemu wypaleniu. Wiele dyskusji na różnych szczeblach kończy się wnioskami, że misja dziejowa Stanów Zjednoczonych pozostaje dziś tylko wizją i mitem wywodzącym się z zapisów konstytucyjnych, kiedy kraj ten budował swą pozycję w świecie, i nie ma wiele wspólnego z rzeczywistością. Pogląd ten podzielają Donald Pase ${ }^{70}$ i Stephen Gardbaum ${ }^{71}$, którzy amerykański exceptionalism uważają za fantazję państwową i mit. Problemy globalne przed którymi stoi USA, jak również brak koncepcji rozwiązania poważnych sporów i wyzwań XXI w., w rezultacie zdają się przytłaczać Amerykę. Zatem związek amerykańskiego exceptionalismu z dzisiejszą rzeczywistością pozostaje jedynie na płaszczyźnie borykania się o to, w jaki sposób utrzymać istniejący pogląd, jak również co należy uczynić aby towarzyszył on Stanom Zjednoczonym w ich obecności na scenie międzynarodowej w roli powszechnie uznawanej pozycji. W obecnych warunkach wydaje się to mało możliwe. Coraz częściej towarzyszące życiu publicznemu współczesne określenie declinism zostało zdefiniowane przez Herberta Londyna jako postmodernistyczna wiara w wyjątkowość USA, a zarazem brak prawa do odgrywania jakiejś wyjątkowej roli pośród innych narodów. Stąd wywodzą się tezy Paula Krugmana o świadomości Amerykanów, że panowanie Stanów Zjednoczonych jako największego

${ }^{66} \mathrm{~J}$. Ceaser, The Origins and Character of American Exceptionalism, American Political Thought - A Journal of Ideas, Institutions, and Culture, Spring 2012, nr 1, s. 3-4.

67 The Center for the Study of the Presidency and Congress, Washington 2011, s. 1-9.

68 K. Tumulty, American exceptionalism, explained, Washington Post, 12.09.2013, nr 77, s. $12-14$.

69 J. Ceaser, op. cit., s. 3-4.

70 D. Pease, The New American Exceptionalism, Minnesota 2009, s. 43-55.

71 S. Gardbaum, The Myth and the Reality of American Constitutional Exceptionalism, Michigan Law Review, December 2008, nr 107/391, s. 391-466. 
narodu świata, ostatecznie się zakończy ${ }^{72}$. Świadomość ta istnieje nie tylko wśród Amerykanów, ponieważ od dłuższego czasu mówi się o upadku znaczenia USA w wielu innych krajach. Wywołuje to gorące spory publicystów na różny sposób analizujących wydarzenia polityczne na świecie: Flory Lewisa, Anthony Lewisa, Toma Wickera, Pata Buchanana, Mateusza Parrisa, Fareeda Zakaria ${ }^{73}$. Jest również przyzwolenie, a nawet akceptacja społeczeństwa dla amerykańskiego exceptionalismu, ale - zgodnie z najnowszymi badaniami - jest bardzo mało dowodów jednostronnych postaw ${ }^{74}$. Wprawdzie niektóre ankiety, tak jak przeprowadzona przez George Mason University, w której około 80\% respondentów zgodziło się z oświadczeniem, że Ameryka jest wyjątkowa, dowodzą że społeczeństwo przekonane jest o istnieniu amerykańskiego exceptionalismu ${ }^{75}$. Nie jest to do końca prawdą, ponieważ wiąże się ze swego rodzaju przyzwyczajeniem do jego obecności od lat, a niekoniecznie świadomością że zjawisko ma rzeczywiste odzwierciedlenie w polityce amerykańskiej ${ }^{76}$. Wolność i demokracja USA, stanowiąca fundament exceptionalismu, nie ma dzisiaj potwierdzenia w rankingach światowych. W przeprowadzonych w 2012 r. badaniach mówi się o częściowej wolności USA, będących w tyle za Australią i Kanadą, oraz o 19 pozycji wśród najbardziej demokratycznych krajów świata, zgodnie z rankingiem amerykańskiej „Economist Intelligence Unit's Index of Democracy”. Podobną pozycję, bo 18, zajęły Stany Zjednoczone w rankingach wolności gospodarczych przeprowadzonych przez Kato i Fraser Institutes, tuż za Chile, Irlandią i Wielką Brytanią ${ }^{77}$ Zatem i w sprawach gospodarczych decydujących niedawno o potędze USA, jej system innowacyjny wymaga zreformowania. Zastój w systemie edukacyjnym, niedostateczne wsparcie dla nauki, techniki, inżynierii i matematyki, grożą poważnym załamaniem czołowej gospodarki światowej. Wywiera to znaczny wpływ na osłabienie i załamanie się przesłanek amerykańskiego exceptionalismu ${ }^{78}$.

Stany Zjednoczone stanowią jedną z najstarszych stabilnych demokracji świata, głęboko osadzoną w kulturze politycznej tego kraju. Wolności ujęte w konstytucji USA zostały przyswojone tak przez Amerykanów, jak i amerykańskie instytucje.

72 H. London, Examining Declinism, http://www.humanevents.com/2010/03/11/examiningdeclinism/, odczyt z 18.01.2014.

73 A. Dowd, Three Centuries of American Declinism, http://www.realclearpolitics.com/articles/2007/08/decli nism.html, odczyt z 18.01.2014.

74 J. Thimm, op. cit., s. 4-16.

75 J. Ceaser, op. cit., s. 4.

76 F. Buckley, American Exceptionalism, George Mason University Law and Economics Research Paper Series, 2013, nr 13(09), s. 3.

77 Ibidem, s. 4.

78 American Exceptionalism, American Decline?..., s. 5. 
Wpłynęło to w znacznym stopniu na ukształtowanie się amerykańskiego exceptionalismu, który wpisany został na stałe w styl funkcjonowania państwowości amerykańskiej ${ }^{79}$. Jednakże, w kontekście jego istnienia bez znaczenia jest tutaj fakt czy poddaje się go krytyce czy nie. Naciski władz USA na exceptionalism koncentrują się w istocie na tworzeniu traktatów gwarantujących rozwiązanie konkretnych globalnych problemów. Tego typu orientacja pozwala wielu krajom uzyskać międzynarodowe uznanie poprzez aprobatę tych traktatów, nawet jeśli się do nich nie zastosują ${ }^{80}$. Mimo, że exceptionalism w wydaniu amerykańskim obecnie ma znacznie słabszą pozycję, to zapewne będzie on jeszcze długo kluczowym elementem w powszechnych dyskusjach i debatach na gruncie międzynarodowej sytuacji politycznej. Jego obecność stanowi niewątpliwie jedno z najważniejszych wyzwań dla USA i światowej opinii publicznej. Amerykański exceptionalism wzbudza silne emocje. Dla wielu Amerykanów jest uosobieniem najlepszych cech związanych z amerykańskim życiem: polityczną wolnością, demokracją, równouprawnieniem prawym i społecznym. Przywołuje on patriotyzm i wdzięczność dla przodków, którzy wybrali życie w Ameryce ${ }^{81}$.

79 A. Bradford, E. Posner, Universal Exceptionalism in International Law, Harvard International Law Journal, 2011, nr 52, s. 40.

80 S. Safrin, The Un-Exceptionalism of U.S. Exceptionalism, Vanderbilt Journal of Transnational Law, 2008, nr 41/1307, s. 1354.

81 G. Wilson, Exceptionalism In a Time of Stress, Harvard Journal of Law \& Public Policy, 2007, nr 32/2, s. 455. 